\title{
Application of nitrogen and sulphur to sunny and shady aspects on South Island dry hill country
}

\author{
L.C. SMITH ${ }^{1}$, J.D. MORTON ${ }^{2}$, K.D. TRAINOR ${ }^{3}$ and W.D. CATTO ${ }^{4}$ \\ ${ }^{1}$ AgResearch, Woodlands Research Station, R.D.1, Invercargill \\ ${ }^{2}$ AgResearch, Invermay Agricultural Centre, PB 50034, Mosgiel \\ ${ }^{3}$ AgResearch, P.O. Box 228, Alexandra \\ ${ }^{4}$ Ballance Agri-Nutrients, PB 12503, Mount Maunganui
}

chris.smith@agresearch.co.nz

\begin{abstract}
There are large differences in pasture growth and composition between aspects in dry hill country (annual rainfall $300-600 \mathrm{~mm}$ ) in South Island dry hill country that could result in different fertiliser nutrient requirements for the grasses and legumes present. To determine these requirements, small plot mowing trials were carried out on sunny and shady aspects on Glenfoyle Station near Tarras and on Omarama Station over 3 years. At the Glenfoyle sites, nitrogen $(\mathrm{N})$ was applied as urea at an average rate of $0,15,30$ and $60 \mathrm{~kg} /$ $\mathrm{ha} / \mathrm{yr}$ and sulphur (S) was applied as gypsum at 0, 10, 20 and $40 \mathrm{~kg} / \mathrm{ha} / \mathrm{yr}$. At the Omarama sites, $\mathrm{N}$ and $\mathrm{S}$ were applied at $0,18,36$ and $71 \mathrm{~kg} / \mathrm{ha} / \mathrm{yr}$. Soil total N $(0.18$ $0.33 \%)$, sulphate-S (3-5 $\mu \mathrm{g} / \mathrm{g})$ and organic-S (1.5-3.5 $\mu \mathrm{g} / \mathrm{g}$ ) levels were low at all sites. Pasture species on the sunny north-west aspect at Glenfoyle were mainly ryegrass $(35 \%$ of total pasture content), flatweeds $(20 \%)$ and subterranean clover $(10 \%)$ with a predominance of browntop (31\%) and white clover $(20 \%)$ on the shady south-east aspect. There was a total pasture production response from $15-60 \mathrm{~kg} \mathrm{~N} / \mathrm{ha} / \mathrm{yr}$ $(12-20 \mathrm{~kg} \mathrm{DM} / \mathrm{kg} \mathrm{N})$ associated with an increase in ryegrass content in Year 2 on the sunny aspect. On the shady aspect there was a total pasture production response from 30-60 kg N/ha/yr (16-21 kg DM/kg N) associated with an increase in browntop content. Increasing rate of $\mathrm{N}$ reduced subterranean clover on the sunny and white clover content on the shady aspect. On the sunny aspect, total pasture production and ryegrass content was increased from the application of $40 \mathrm{~kg} \mathrm{~S} /$ ha/yr. Pasture composition at Omarama consisted mainly of Danthonia species (41\%) and Bromus tectorum (30\%) on the sunny north aspect and cocksfoot $(39 \%)$ and browntop (11\%) on the shady south aspect with less than $3 \%$ legume content on either aspect. On both aspects, there was a response in pasture production from rates of 18-71 kg N/ha (19-36 kg DM/ $\mathrm{kg} \mathrm{N}$ ) but this was not associated with a consistent response from individual pasture species. There was no response in total pasture production to $\mathrm{S}$. The overall results indicate that high responses to $\mathrm{N}$ can be achieved
\end{abstract}

from a range of grass species on both sunny and shady aspects and that soil sulphate-S levels of $3 \mu \mathrm{g} / \mathrm{g}$ and greater are required for optimal growth of higher fertility responsive pasture species.

Keywords: aspect, differential application, dry hill country, grasses, legumes, nitrogen, sulphur

\section{Introduction}

In dry hill country with annual rainfall of $800 \mathrm{~mm}$ and less, there can be a strong effect of aspect on the presence and growth of native and introduced grasses and legumes. On sunny north aspects, soil moisture is lower and soil temperature higher, especially in spring, than on shady south aspects (Smith unpublished data). As for most pastoral systems, forage production depends on an adequate supply of nitrogen $(\mathrm{N})$ for the predominant grasses, which is normally mostly fixed by legumes. The persistence and growth of perennial legumes such as white clover relies on an adequate supply of soil moisture during summer and autumn when their higher temperature requirements are met. Therefore there is usually more white clover present on shady aspects (Gillingham et al. 1998), which transfer N to high fertility responsive grasses such as cocksfoot and ryegrass in animal excreta and through decay of non-grazed biomass. Annual legumes such as subterranean clover, which grow mainly in late spring, require adequate moisture during spring to germinate and subsequently grow and set seed for the next season. Because of greater drought tolerance, subterranean clover growth is greater on sunny aspects, but only makes a small contribution to total pasture growth (Gillingham et al. 1998). The presence of different grass species can vary between aspects and be independent of legume content, which suggests that other factors such as utilisation of pasture by grazing and the camping behaviour of sheep may be important. For example, Gillingham et al. (1998) reported a greater presence of ryegrass on sunny rather than shady aspects, and a greater presence of browntop on shady rather than sunny aspects. In inland areas such as Central Otago with its continental climate and high altitude, the onset of 
pasture growth in the spring can be as late as October. There is an opportunity to stimulate grass growth on the sunny aspects which warm up faster, by application of fertiliser $\mathrm{N}$ in early to mid-spring to provide more feed at lambing.

Sulphur (S) is mainly required by legumes for growth and $\mathrm{N}$ fixation and is deficient in most undeveloped Central Otago Semiarid and Pallic soils (Ludecke \& Leamy 1972). On extensively farmed dry hill country where aerial application costs per hectare are high, there is a potential advantage from being able to differentially apply fertiliser $\mathrm{S}$ to aspects where responsive pasture species are present. Phosphorus (P) is usually supplied by the soil in adequate amounts in the weakly weathered Semiarid and Pallic soils but may be required on the higher altitude Brown soils (Ludecke \& Leamy 1972).

The economic benefits from differential topdressing of dry North Island hill country have been quantified in a 3-year farmlet study and are reported in this conference proceedings (Gillingham et al. 2004). Differential application of $\mathrm{P}$ and $\mathrm{S}$ on the easy slopes where legume was present and $\mathrm{N}$ and $\mathrm{S}$ on the steep slopes with little legume, compared with a uniform application of $\mathrm{P}$ and $\mathrm{S}$ on all slopes resulted in a $20 \%$ increase in net margin from the farmlets that were differentially fertilised.

In order to test the effect of the application of $\mathrm{N}$ and $\mathrm{S}$ on different aspects, trials were carried out in Central Otago and the Mackenzie Basin.

\section{Materials and methods \\ Sites}

The Central Otago sites were on north-west (sunny) and south-east (shady) aspects at Glenfoyle Station, between Tarras and Hawea, located at $470 \mathrm{~m}$ above sea level on an Arrow Pallic soil on a $28^{\circ}$ slope. Initial soil test values for the sunny and shady aspects respectively were pH 5.7 and 5.6, Olsen $\mathrm{P} 5$ and $8 \mu \mathrm{g} / \mathrm{ml}$, quick test (QT) calcium (Ca) 4 and 5, QT potassium (K) 10 and 7, QT magnesium (Mg) 16 and 19, sulphate-S 4 and $5 \mu \mathrm{g} /$ g, organic-S 2 and $4 \mu \mathrm{g} / \mathrm{g}$, organic matter 5.9 and $6.5 \%$ and total $\mathrm{N} 0.26$ and $0.33 \%$. The dominant grass on the sunny aspect was ryegrass (average $35 \%$ of total pasture composition over 3 years) and the dominant legume subterranean clover $(10 \%)$. There was also a high content of flatweeds $(20 \%)$. On the shady aspect, browntop (average $31 \%$ of total pasture composition over Years 2 and 3) and white clover (20\%) predominated.

The Mackenzie Basin sites were on north (sunny) and south (shady) aspects at Omarama Station, located at $520 \mathrm{~m}$ above sea level on an Otematata Semiarid soil on a similar slope to the Central Otago sites. Initial soil test values for the sunny and shady aspects respectively were $\mathrm{pH} 6.0$ and 5.7, Olsen P 15 and $8 \mu \mathrm{g} / \mathrm{ml}$, QT Ca 6 and 8, QT K 10 and 6, QT Mg 22 and 28, sulphate-S 5 and $5 \mu \mathrm{g} / \mathrm{g}$, organic-S 3 and $2 \mu \mathrm{g} / \mathrm{g}$, organic matter 3.5 and $5.2 \%$ and total N 0.18 and $0.29 \%$. Danthonia species (average $41 \%$ of total pasture composition over Years 2 and 3) and Bromus tectorum (30\%) were the dominant grass species on the sunny aspect and cocksfoot $(39 \%)$ and browntop (11\%) were dominant on the shady aspect with less than $3 \%$ legume on either aspect.

\section{Design and treatments}

The trial design at all sites was a $\mathrm{N}$ x $\mathrm{S}$ fertiliser rate randomised block factorial with 3 replicates. At Glenfoyle, treatments of $0,15,30$ and $60 \mathrm{~kg} \mathrm{~N} / \mathrm{ha}$ as urea and $0,12.5,25$ and $50 \mathrm{~kg} \mathrm{~S} / \mathrm{ha}$ as gypsum were first applied in March 2000 and these rates of $\mathrm{N}$ re-applied in September 2001 and 2002, and S re-applied in September 2002. In September 2001, 0, 5, 10 and $20 \mathrm{~kg}$ $\mathrm{S} /$ ha were applied. At Omarama, treatments of $0,13,27$ and $53 \mathrm{~kg} \mathrm{~N}$ and S/ha were first applied in August 2001 with 0, 20, 40 and $80 \mathrm{~kg} \mathrm{~N}$ and S/ha re-applied in August 2002 and 2003. At Glenfoyle, $30 \mathrm{~kg} \mathrm{P} / \mathrm{ha}$ as monocalcium phosphate and $33 \mathrm{~kg} \mathrm{~K} / \mathrm{ha}$ as potassium chloride and at Omarama, $\mathrm{P}$ (as mono-calcium phosphate) and $\mathrm{K}$ (as potassium chloride) dressings of $33 \mathrm{~kg} / \mathrm{ha}$ were applied at the same time as the treatments. In addition, $160 \mathrm{~g}$ sodium molybdate/ha was applied to each plot at Glenfoyle in March 2000.

\section{Measurements}

Monthly rainfall was recorded at Grandview Station (3 $\mathrm{km}$ south of Glenfoyle sites) from August 2000 to February 2001 and at the Glenfoyle sites from March 2001 to April 2003. At the Omarama sites, rainfall was recorded from September 2001 to March 2003 and from Tara Hills (5 km south of Omarama sites) from April 2003 to April 2004. Soil moisture in the top $100 \mathrm{~mm}$ was measured gravimetrically at irregular 1-3 monthly intervals during the spring and summer of 2001/2002 and 2002/2003 at all sites. In June 2001, July 2002 and March 2003 at Glenfoyle and June 2002 and 2003 and May 2004 at Omarama, 15 soil cores from each plot were sampled to $75 \mathrm{~mm}$ depth and analysed for sulphateS. Pasture production was assessed from 5 pasture plate meter readings from each plot when pasture mass reached at least $1500 \mathrm{~kg} \mathrm{DM} / \mathrm{ha}$. The plate readings were calibrated against pasture DM mass measured from cutting 7 quadrats to ground level for each cut at each site. After each measurement, the plots were trimmed and the clippings discarded. Pasture composition was assessed by dissection of sub-samples of 5 bulked samples from each plot into separate pasture species. Analysis of variance was carried out on the soil sulphate-S and pasture production and composition data 
using GENSTAT to detect significant differences between treatments.

\section{Results}

\section{Rainfall and soil moisture}

Annual rainfall was $460 \mathrm{~mm}$ in 2000/2001, $274 \mathrm{~mm}$ in $2001 / 2002$ and $291 \mathrm{~mm}$ (up to May) in 2002/2003 at Glenfoyle and $410 \mathrm{~mm}$ in 2001/2002, $338 \mathrm{~mm}$ in 2002/ 2003 and $320 \mathrm{~mm}$ in 2003/2004 (up to April) at Omarama. There was large variation in monthly rainfall at both sites (Figure 1). Soil moisture content averaged 11 and $9 \%$ respectively for the sunny aspects at Glenfoyle and Omarama and $21 \%$ for both shady aspects.

\section{Soil S}

Application of 20 and $40 \mathrm{~kg} \mathrm{~S} / \mathrm{ha} / \mathrm{yr}$ significantly increased soil sulphate-S levels compared with 0 and 10 $\mathrm{kg} \mathrm{S} / \mathrm{ha} / \mathrm{yr}$ on the Glenfoyle sunny aspect in 2001 and 2002 while in 2003 on the sunny aspect and 2002 and 2003 on the shady aspect, soil sulphate-S was significantly increased by each rate of $\mathrm{S}$ (Table 1). Rates of 36 and $71 \mathrm{~kg} / \mathrm{ha} / \mathrm{yr}$ significantly increased soil sulphate-S compared with 0 and $18 \mathrm{~kg} \mathrm{~S} / \mathrm{ha} / \mathrm{yr}$ on the Omarama sunny and shady aspect in 2003. In 2002 and 2004, application of $71 \mathrm{~kg} \mathrm{~S} / \mathrm{ha} / \mathrm{yr}$ resulted in significantly higher soil sulphate-S levels than the other rates on both aspects.

Figure 1 Monthly rainfall at or near the Glenfoyle and Omarama sites.

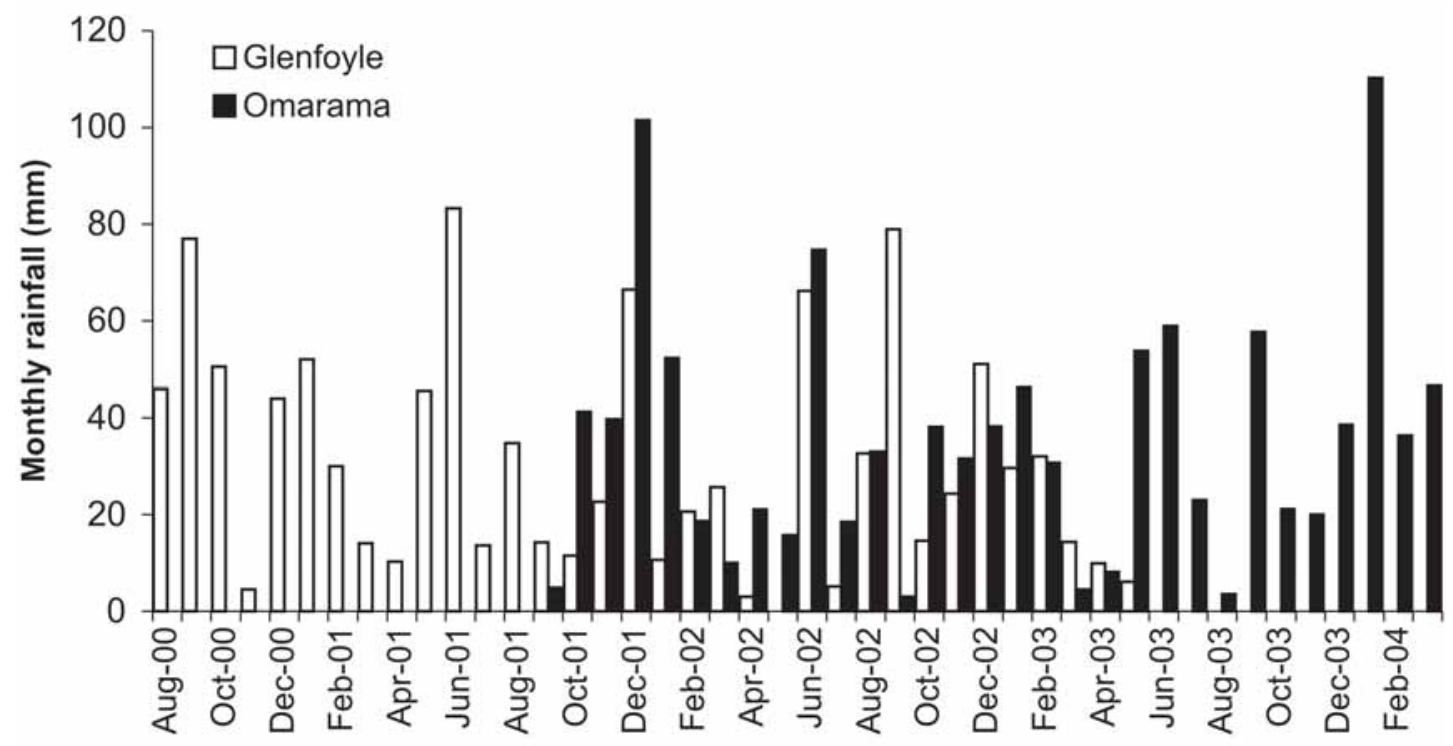

Table 1 Effect of average rate of $S(\mathrm{~kg} / \mathrm{ha} / \mathrm{yr})$ on soil sulphate-S levels $(\mu \mathrm{g} / \mathrm{g})$. LSD is for the significance level indicated.

\begin{tabular}{|c|c|c|c|c|c|c|}
\hline \multirow[b]{2}{*}{ Glenfoyle } & \multicolumn{3}{|c|}{ Sunny aspect } & \multicolumn{3}{|c|}{ Shady aspect } \\
\hline & 2001 & 2002 & 2003 & 2001 & 2002 & 2003 \\
\hline 0 & 3 & 2 & 2 & 5 & 4 & 3 \\
\hline 10 & 3 & 2 & 4 & 6 & 6 & 6 \\
\hline 20 & 4 & 4 & 6 & 5 & 7 & 8 \\
\hline 40 & 4 & 6 & 9 & 7 & 12 & 11 \\
\hline Significance & * & $* \star *$ & $\star \star * *$ & NS & $\star \star * *$ & $* \star *$ \\
\hline LSD & 0.7 & 0.8 & 1.2 & & 1.2 & 1.5 \\
\hline Omarama & 2002 & 2003 & 2004 & 2002 & 2003 & 2004 \\
\hline 0 & 4 & 2 & 2 & 4 & 8 & 3 \\
\hline 18 & 4 & 5 & 3 & 7 & 14 & 10 \\
\hline 36 & 4 & 10 & 8 & 7 & 24 & 17 \\
\hline 71 & 6 & 13 & 25 & 10 & 43 & 44 \\
\hline Significance & $\dagger$ & $* *$ & 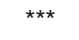 & $\star \star \star ~$ & $\star \star \star$ & $\star \star \star *$ \\
\hline LSD & 1.6 & 5.9 & 12.0 & 1.0 & 9.0 & 18.0 \\
\hline
\end{tabular}

NS not significant, $\dagger P<0.10,{ }^{*} P<0.05,{ }^{* *} P<0.01,{ }^{* * *} P<0.001$. 
Table 2 Pasture production (kg DM/ha/yr) from $\mathrm{N}$ and $\mathrm{S}$ application (kg/ha/yr). Efficiency of $\mathrm{N}$ response (kg DM/ $\mathrm{kg} \mathrm{N}$ ) in brackets.

\begin{tabular}{|c|c|c|c|c|c|}
\hline \multirow{2}{*}{$\begin{array}{l}\text { Glenfoyle sunny } \\
\text { Nitrogen }\end{array}$} & \multirow{2}{*}{0} & \multirow[b]{2}{*}{10} & \multirow[b]{2}{*}{20} & \multirow[b]{2}{*}{40} & \multirow[t]{2}{*}{ Mean } \\
\hline & & & & & \\
\hline 0 & 4375 & 3756 & 3766 & 3423 & 3830 \\
\hline 15 & 3578 & 4345 & 3947 & 4664 & $4133(20)$ \\
\hline 30 & 4166 & 3675 & 4220 & 4659 & $4180(12)$ \\
\hline 60 & 3658 & 5565 & 4911 & 5357 & $4873(17)$ \\
\hline \multirow{2}{*}{ Mean } & 3944 & 4335 & 4211 & 4256 & 4254 \\
\hline & LSD & Signif. & & & \\
\hline $\mathrm{N}$ main effect & 417 & $\star \star \star$ & & & \\
\hline$S$ main effect & 347 & $\dagger$ & & & \\
\hline $\mathrm{N} \times \mathrm{S}$ interaction & 835 & ** & & & \\
\hline \multicolumn{6}{|l|}{ Glenfoyle shady } \\
\hline 0 & 3078 & 3386 & 3380 & 4268 & 3528 \\
\hline 15 & 3446 & 3453 & 3934 & 4322 & 3788 \\
\hline 30 & 4166 & 4147 & 4013 & 3729 & $4014(16)$ \\
\hline 60 & 4762 & 4649 & 4666 & 5173 & $4813(21)$ \\
\hline \multirow[t]{2}{*}{ Mean } & 3863 & 3909 & 3998 & 4373 & 4036 \\
\hline & LSD & Signif. & & & \\
\hline $\mathrm{N}$ main effect & 680 & ** & & & \\
\hline \multirow{2}{*}{$\begin{array}{l}S \text { main effect } \\
\mathrm{N} \times \mathrm{S} \text { interaction }\end{array}$} & & NS & & & \\
\hline & & NS & & & \\
\hline \multicolumn{6}{|l|}{ Omarama sunny } \\
\hline & 0 & 18 & 36 & 71 & \\
\hline 0 & 1640 & 1866 & 1697 & 1658 & 1715 \\
\hline 18 & 2617 & 2470 & 2168 & 2229 & $2371(36)$ \\
\hline 36 & 1859 & 2762 & 2919 & 2727 & 2567 (24) \\
\hline 71 & 3819 & 3864 & 2514 & 3669 & 3467 (25) \\
\hline \multirow[t]{2}{*}{ Mean } & 2484 & 2740 & 2324 & 2571 & 2530 \\
\hline & LSD & Signif. & & & \\
\hline $\mathrm{N}$ main effect & 659 & 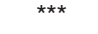 & & & \\
\hline \multirow{2}{*}{$\begin{array}{l}S \text { main effect } \\
\mathrm{N} \times \mathrm{S} \text { interaction }\end{array}$} & & NS & & & \\
\hline & & NS & & & \\
\hline \multicolumn{6}{|l|}{ Omarama shady } \\
\hline 0 & 5230 & 4197 & 4781 & 4435 & 4661 \\
\hline 18 & 4876 & 4879 & 5332 & 5652 & $5185(29)$ \\
\hline 36 & 5874 & 5004 & 5265 & 5683 & $5456(22)$ \\
\hline \multirow{3}{*}{ Mean } & 5286 & 6332 & 5687 & 6773 & $6019(19)$ \\
\hline & 5316 & 5103 & 5266 & 5636 & 5330 \\
\hline & LSD & Signif. & & & \\
\hline $\mathrm{N}$ main effect & 615 & ${ }_{* \star *}$ & & & \\
\hline$S$ main effect & & NS & & & \\
\hline $\mathrm{N} \times \mathrm{S}$ interaction & & NS & & & \\
\hline
\end{tabular}

\section{Pasture production}

There were significant responses in pasture DM production to $\mathrm{N}(\mathrm{P}<0.001)$ at 60 compared with the three lower rates at the Glenfoyle sites. At the Omarama sites, 36 and $71 \mathrm{~kg} \mathrm{~N} / \mathrm{ha} / \mathrm{yr}$ resulted in significantly greater DM production than $0 \mathrm{~kg} \mathrm{~N} / \mathrm{ha} / \mathrm{yr}$ but there was no significant difference in DM production between 18 and $36 \mathrm{~kg} \mathrm{~N} / \mathrm{ha} / \mathrm{yr}$ (Table 2). The average efficiency of response to $\mathrm{N}$ was similar between all four sites and tended to level off or diminish above the lowest rate of $\mathrm{N}$ at all sites except Glenfoyle shady where efficiency of $\mathrm{N}$ use was greatest at the highest rate. Pasture production was significantly greater at 10 compared with $0 \mathrm{~kg} \mathrm{~S} / \mathrm{ha} /$ yr on the Glenfoyle sunny aspect but there were no significant responses in pasture production to $S$ at the other sites. On the Glenfoyle sunny aspect, there was a significant positive response in pasture production to $S$ where $\mathrm{N}$ was applied but a significant negative response without $\mathrm{N}$ fertiliser. Where no $\mathrm{S}$ was applied there was a non-significant response in pasture production to $\mathrm{N}$ but a significant response where $\mathrm{S}$ was also applied.

\section{Pasture composition}

On the Glenfoyle sunny aspect, increasing the rate of 
Figure 2 Effect of fertiliser $\mathrm{N}$ and $\mathrm{S}$ fertiliser application on a) ryegrass and b) subterranean clover content on the sunny aspect and $\mathrm{N}$ fertiliser application on c) browntop and d) white clover content on the shady aspect at Glenfoyle.
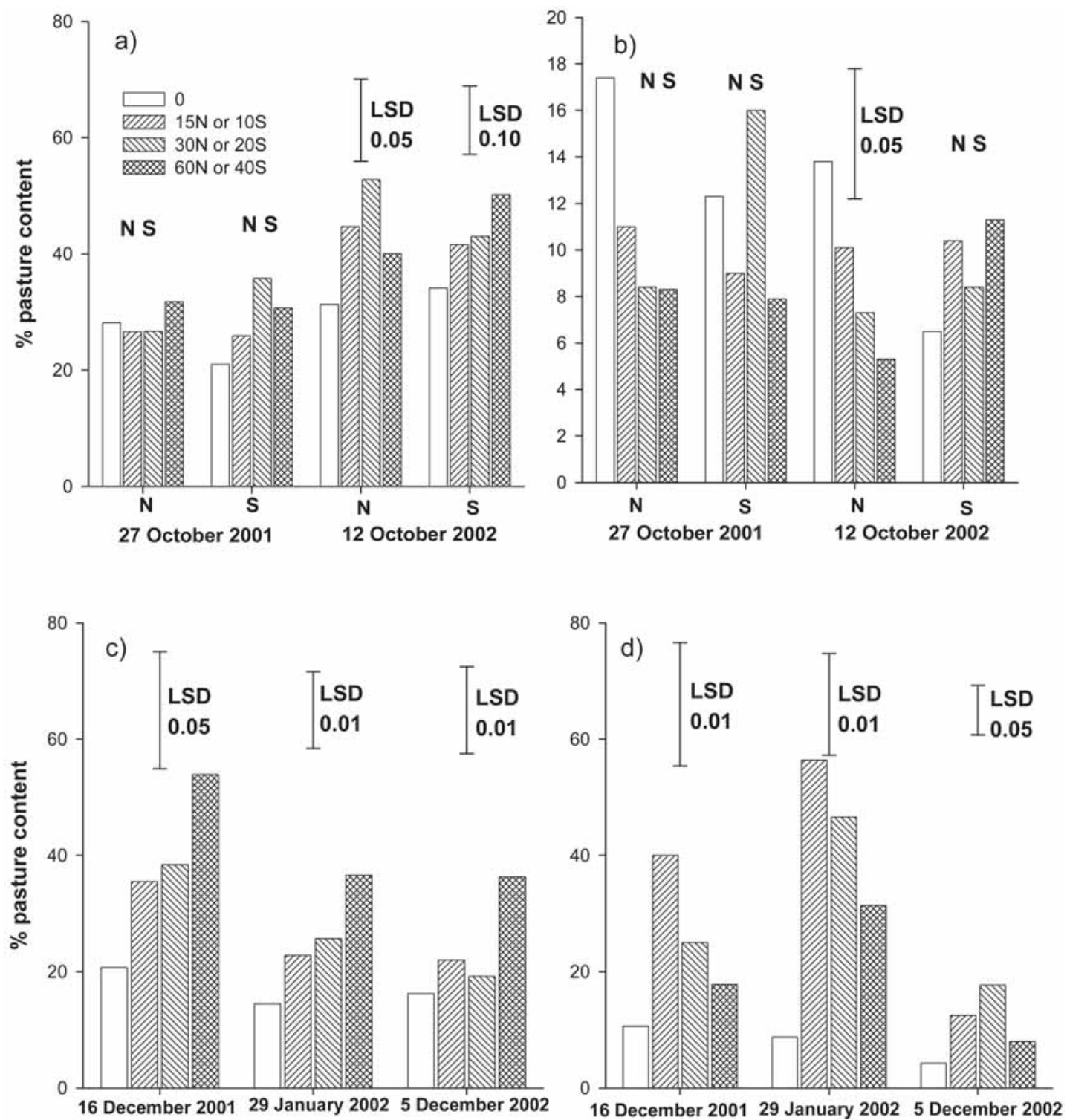

$\mathrm{N}$ from 0 to $30 \mathrm{~kg} / \mathrm{ha} / \mathrm{yr}$ significantly increased ryegrass and reduced subterranean clover content in October 2002 (Figure 2). There was also a significant increase in ryegrass content at 40 compared with $0 \mathrm{~kg}$ $\mathrm{S} / \mathrm{ha} / \mathrm{yr}$ in October 2002. Browntop content was significantly greater at $60 \mathrm{~kg} \mathrm{~N} / \mathrm{ha} / \mathrm{yr}$ compared with some or all of the lower rates in December 2001 and 2002 and January 2002 on the Glenfoyle shady aspect but white clover content was significantly lower at 60 compared to $15 \mathrm{~kg} \mathrm{~N} / \mathrm{ha} / \mathrm{yr}$ in December 2001 and 2002. At Omarama on the sunny aspect, the content of
Bromus tectorum was significantly lower at $71 \mathrm{~kg} \mathrm{~N} /$ $\mathrm{ha} / \mathrm{yr}$ compared with the other three rates and the content of Danthonia species was significantly higher from $\mathrm{N}$ application than control in October 2002 (Figure 3). The content of Bromus tectorum in November 2003 significantly increased with N application whereas the content of Danthonia species was significantly lower at 71 compared with 0 and 18 $\mathrm{kg} \mathrm{N} / \mathrm{ha} / \mathrm{yr}$. On the shady aspect, browntop and cocksfoot content was significantly lower at 71 compared with 18 or $36 \mathrm{~kg} \mathrm{~N} / \mathrm{ha} / \mathrm{yr}$. 
Figure 3 Effect of fertiliser $\mathrm{N}$ application on a) Bromus tectorum and b) Danthonia species content on the sunny aspect and c) cocksfoot and d) browntop content on the shady aspect at Omarama.
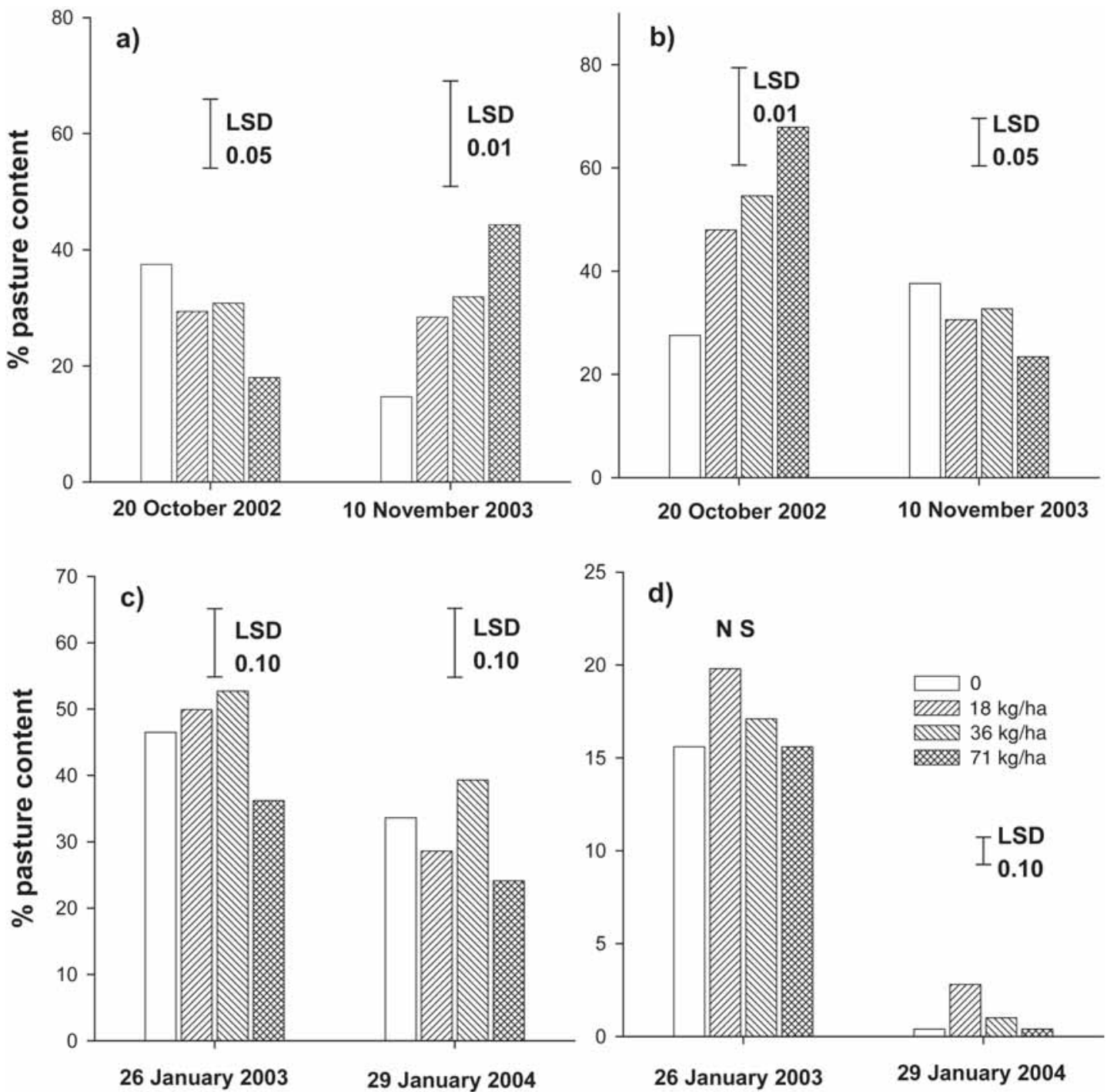

\section{Discussion}

As would be expected with these extremely low annual rainfalls (338-460 $\mathrm{mm})$, mean annual pasture production was also low $(4036-5330 \mathrm{~kg} \mathrm{DM} / \mathrm{ha}$ at the highest rate of $\mathrm{N}$ and $\mathrm{S}$ ). Despite the contrast in the fertility requirements of the grass species on each aspect, production responses to $\mathrm{N}$ fertiliser were universally high due to the low soil $\mathrm{N}$ content as a result of the low or nil background legume contribution. Luscombe (1980) also reported a similar level of response to $\mathrm{N}$ from different non-ryegrass species compared with ryegrass. At Glenfoyle, the increase in ryegrass (sunny aspect) and browntop (shady aspect) content from $\mathrm{N}$ application would probably have caused the decrease in subterranean clover (sunny aspect) and white clover (shady aspect) through shading.

This depressive effect of $\mathrm{N}$ on legume growth was also reported by Gillingham et al. (1998). At Glenfoyle, the dominant legume presence of subterranean clover on the sunny and white clover on the shady aspect, as also measured by Gillingham et al. (1998) would have been expected as a result of more available soil moisture on the shady aspect. The associated dominant ryegrass on the sunny and browntop on the Glenfoyle shady aspect could be related to the previous poor utilisation by grazing of pasture on the shady aspect compared with more sparse pasture cover and possible camping by sheep on the sunny aspect. 
The lack of response to $\mathrm{S}$ application from subterranean clover on the Glenfoyle sunny aspect despite mean soil sulphate-S levels for the control of less than $3 \mu \mathrm{g} / \mathrm{g}$ suggested that subterranean clover is tolerant of low soil S supply. On the Glenfoyle sunny aspect, the dominant ryegrass was responsive to $\mathrm{S}$ application and the total production response to $\mathrm{N}$ was reliant on the application of $\mathrm{S}$ fertiliser. Where white clover was the dominant legume on the Glenfoyle shady aspect, soil sulphate-S levels only decreased to $3 \mu \mathrm{g} / \mathrm{g}$ in 2003 so must have been adequate for the lack of response to applied $\mathrm{S}$ to have been measured.

Large responses in relative pasture production (from 15 to $85 \%$ of maximum) to $100 \mathrm{~kg} \mathrm{~S} /$ ha were measured over 3 years at 2 shady and 2 sunny hill sites with high legume contents (78-95\%) on a Pallic soil with initial sulphate-S levels of $2 \mu \mathrm{g} / \mathrm{g}$ (McIntosh et al. 1985).

\section{Conclusions}

$\mathrm{N}$ fertiliser application on dry hill country prior to lambing can be used to increase feed supply to lambing ewes. The response in pasture production was similar for a range of grass species present on both sunny and shady aspects. However legume content at Glenfoyle was suppressed from shading by the grasses present. Low soil sulphate-S levels (average less than $3 \mu \mathrm{g} / \mathrm{g}$ ) for the controls on the sunny aspects at both sites only limited ryegrass growth, with tolerance to a low $\mathrm{S}$ supply being shown by the other less fertility responsive pasture species. These results demonstrate that in hill country with lower rainfall, aspect alone cannot be used as the criteria on where to apply $\mathrm{N}$ but the content of grass and legume species are more useful indicators. Fertiliser $\mathrm{S}$ is required if there is a reasonable content ( $>30 \%$ cover) of high fertility responsive pasture species such as ryegrass and if soil sulphate-S levels are $3 \mu \mathrm{g} / \mathrm{g}$ or less, both to optimise legume production and to ensure that the maximum response from grasses to $\mathrm{N}$ fertiliser is achieved.

\section{ACKNOWLEDGEMENTS}

We thank Ballance Agri-Nutrients for funding the research, Sue Smith for pasture dissections and Alan Kane and Richard Subtill for providing trial sites.

\section{REFERENCES}

Gillingham, A.G.; Gray, M.H.; Smith, D.R. 1998. Pasture responses to phosphorus and nitrogen fertilisers on dry hill country. Proceedings of the New Zealand Grassland Association 60: 135-140.

Gillingham, A.G.; Gray, M.W.; Morton, J.D. 2004. Animal production, economic results and lessons from nitrogen fertiliser use on dry hill country. Proceedings of the New Zealand Grassland Association 66: 35-40.

Ludecke, T.E.; Leamy, M.L. 1972. Fertiliser use and grassland improvement on Central Otago hill and mountain soils. Tussock Grasslands and Mountain Lands Institute Review 25: 14-21.

Luscombe, P.C. 1980. Seasonal nitrogen deficiency in hill country pastures. New Zealand Journal of Experimental Agriculture 2: 117-122.

McIntosh, P.D.; Sinclair, A.G.; Enright, P.D. 1985. Responses of legumes to phosphorus and sulphur fertilisers on 2 toposequences of North Otago soils. New Zealand Journal of Agricultural Research 28: 505-515. 